\title{
EVALUATION AND CONSULTATION: TOOLS FOR THE INCLUSIVE MUSEUM ${ }^{1}$
}

\author{
LAURA CROSSLEY
}

https://doi.org/10.5817/MuB2017-1-6

The inclusive museum ensures that everything it does is designed to meet the needs of its audiences. In order to do this, the museum must "understand [its audiences] and put them at the centre of [their] practice". ${ }^{2}$ Evaluation and consultation enables museums to increase their understanding of their audiences, including who does and does not visit and why, and audiences' perceptions, experiences and expectations of the museum. The inclusive museum represents and reflects its communities, responding to and meeting their needs, ${ }^{3}$ and I would suggest that, in order to perform these duties effectively, the inclusive museum must therefore understand its audiences, actively seeking their views and feedback and empowering them to engage in dialogue with museum staff.

In a blog post on the National Museums Liverpool website, Fleming suggests that the democratic museum, “...involves the public in many ways, not solely as

1 The article is based on a lecture I gave at Masaryk University in December 2015. Thank you to the Department of Archaeology and Museology at Masaryk University, including Lucie Jagošová and Otakar Kirsch, for inviting me to give the lecture.

2 LUKE, Jessica J. and Jeanine E. ANCELET. The Role of Evaluation in Reimagining the Art Museum. Journal of Museum Education [online]. 2014, vol. 39, no. 2, p. 204 [cit. 2017-03-16]. Available from www: <http://www.tandfonline.com. ezproxy4.lib.le.ac.uk/doi/pdf/10.1080/10598650. 2014.11510810 ? needAccess $=$ true $>$.

3 BLACK, Graham. The Engaging Museum. Devel oping Museums for Visitor Involvement [online].

London and New York: Taylor and Francis, 2005,

p. 59 [cit. 2017-03-23]. Available from www:

$<$ http://ebookcentral.proquest.com.ezproxy3.

lib.le.ac.uk/lib/leicester/detail.action?do-

cID $=1075158>$. visitors, through consultation, advice and participation - it is integrated into the lives of its communities, it contains their voices, it is based on dialogue". ${ }^{4}$ Museum staff who engage in active dialogue with diverse audiences, and act upon the findings of this dialogue, are acknowledging the importance of seeking views, ideas and feedback and empowering audiences to influence and change museum approaches and practices. Active dialogue between museums and audiences also supports audiences to construct new understandings of the museum. ${ }^{5}$ This coming together of museums and audiences to jointly deepen knowledge and understanding of each other is a powerful process and one that, in my view, supports audiences to feel ownership of the museum.

Working in an inclusive way by conducting, and responding to, evaluation and exploring the views of diverse audiences also supports museums' "longevity and vitality" ${ }^{\prime}$ ensuring that museums

\footnotetext{
4 FLEMING, David. Dr David Fleming: "What does the democratic museum look like?". In $\mathrm{Na}$ tional Museums Liverpool Blog [online]. Liverpool: National Museums Liverpool, 2014 [cit. 201703-23]. Available from www: <http://blog.liverpoolmuseums.org.uk/2014/07/dr-david-flemingwhat-does-the-democratic-museum-look-like/>.

5 PRESKILL, Hallie. Museum Evaluation without Borders: Four Imperatives For Making Museum Evaluation More Relevant, Credible, and Useful. Curator. The Museum Journal [online]. 2011, vol. 54, no. 1, p. 98 [cit. 2017-22-03]. Available from www: <http://onlinelibrary.wiley.com.ezproxy4. lib.le.ac.uk/doi/10.1111/j.2151 -6952.2010.00072.x/epdf>

6 STEELE-INAMA, Marley. Building Evaluation Capacity as a Network of Museum Professionals Journal of Museum Education [online]. 2015, vol. 40, no. 1, p. 79 [cit. 2017-03-16]. Available from www: <http://www.tandfonline.com.ezproxy4.
}

retain their "relevance and worth". Evaluation and consultation can also directly contribute to audience development ${ }^{8}$ by supporting museum staff to reach out to, and engage in dialogue with, people who have never previously visited the museum, with whom they can start to build long-term relationships.

The inclusive museum must not stop consulting and evaluating when a particular project, activity or programme has come to an end. Black suggests that audiencecentered museums must not only gain, but also constantly update, their knowledge and understanding of visitors and potential visitors; regular evaluation is vital in supporting continual improvement. ${ }^{9}$ Luke and Ancelet use the phrase 'thinking evaluatively' to describe a situation where museums continually “..consider their visitors' needs, attitudes, perceptions and experiences" and place these at the centre of "everything they do across each department and in each stage of planning and delivery". ${ }^{10}$ The

lib.le.ac.uk/doi/pdf/10.1080/10598650.2015.1151 0836 ? needAccess $=$ true $>$.

7 Ibidem, p. 79

8 Black describes audience development as, "a specific policy of reaching out to new audien ces previously under-represented in the museum". BLACK, Graham. The Engaging Museum. Developing Museums for Visitor Involvement [online]. London and New York: Taylor and Francis, 2005, p. 47 [cit. 2017-03-23]. Available from www: <http:// ebookcentral.proquest.com.ezproxy3.lib.le.ac.uk lib/leicester/detail.action?docID $=1075158>$. ISBN 0-415-34557.

9 Ibidem, pp. 3-5.

10 LUKE, Jessica J. and Jeanine E. ANCELET. The Role of Evaluation in Reimagining the Art Museum. Journal of Museum Education [online]. 2014, vol. 39, no. 2, p. 200 [cit. 2017-03-16]. 
inclusive museum is, by necessity, also the evaluative museum.

\section{What can museums evaluate and with whom can they consult?}

Black lists a range of items which museums can evaluate, such as exploring who is visiting and why, who is not visiting and why, ${ }^{11}$ how far people travel to the site, how often and when people visit, whether the museum is accessible (for example, disabled access, visitor facilities, parking) and the impact of a museum visit or participation in a programme or project upon visitors. ${ }^{2}$ Evaluation can also support us to find out what visitors and non-visitors expect from a museum, their perceptions of a museum, and what people want from museums. ${ }^{13}$

Preskill suggests that "collecting data from a range of sources"14 creates a more useful evaluation as this supports a museum to explore a programme or project's overall impact. Seeking the views of diverse audiences also

Available from www: <http://www.tandfonline. com.ezproxy4.lib.le.ac.uk/doi/pdf/10.1080/10598 650.2014.11510810? needAccess $=$ true $>$.

11 Black suggests that barriers to visiting may include lack of commitment from the museum, lack of museum resources, audience perceptions that the museum is irrelevant or unwelcoming, lack of time, lack of audience awareness, poor physical access to the site, a lack of specific facilities, or costs of entry. BLACK, Graham. The Engaging Museum. Developing Museums for Visito Involvement [online]. London and New York: Taylor and Francis, 2005, p. 55 [cit. 2017-03-23]. Available from www: <http://ebookcentral.proquest. com.ezproxy3.lib.le.ac.uk/lib/leicester/detail. action?docID $=1075158>$. ISBN 0-415-34557.

12 BLACK, Graham. The Engaging Museum. Developing Museums for Visitor Involvement [online] London and New York: Taylor and Francis, 2005, pp. 16-17 [cit. 2017-03-23]. Available from www: $<$ http://ebookcentral.proquest.com.ezproxy3. lib.le.ac.uk/lib/leicester/detail.action?do$\mathrm{cID}=1075158>$.

13 Ibidem, pp. 16-17.

14 PRESKILL, Hallie. Museum Evaluation without Borders: Four Imperatives For Making Museum Evaluation More Relevant, Credible, and Useful. Curator. The Museum Journal [online]. 2011, vol. 54, no. 1, p. 96 [cit. 2017-22-03]. Available from www: <http://onlinelibrary.wiley.com.ezproxy4 lib.le.ac.uk/doi/10.1111/j.2151-

$-6952.2010 .00072 . x /$ epdf $>$. enables museum staff to work in a more audience-centered way by gaining an understanding of what people want from, and how they perceive and experience, the museum. As well as talking to audiences, consider consulting with staff, volunteers and trustees, all of whom can give an internal perspective on the museum that can be compared and contrasted to audiences' perspectives.

\section{Evaluation structure}

Evaluation can be undertaken before, during and after a project happens.

\section{- Front-end evaluation is} conducted before a project begins. This explores what people want from the museum, exhibition, programme, project or event that is being created before any decisions have been taken. For example, people could be asked what themes and methods of interpretation they feel should be included in an exhibition.

- Formative evaluation is collected throughout the development of a project before it is complete, enabling museum staff to test designs and ideas whilst they are still being planned. For example, visitors could be asked for their responses to proposed exhibition designs. This evaluation can highlight whether proposed elements of projects are not working and gives staff the opportunity to remedy this.

\section{- Summative evaluation happens} at the end of a project and measures the extent to which a project has met its objectives and the impacts that the project has on people. For example, visitors to an exhibition could be asked for their views on the exhibition and what they learnt from their visit. This evaluation explores the extent to which the approach a museum has worked, and can be used to develop and improve future activities.

Each stage of the evaluation process is important, but perhaps front-end and formative are of particular importance to the inclusive museum; these stages give museum staff the opportunity to talk to visitors and non-visitors in order to get a broad understanding of the needs, motivations, likes and dislikes of diverse audiences. Consulting with people before and during a project can also give people who take part in consultation a sense of ownership over a project. In addition, frontend and formative evaluation helps to ensure that decisions are not made on the basis of one person's instincts, ${ }^{15}$ ensuring a collaborative, more democratic approach to projects.

\section{Planning the evaluation}

Before commencing evaluation, you need to plan the research. Consider why are you collecting the data and what you need to find out; this will help focus your evaluation and write research questions, which could include, for example, 'What have visitors learnt as a result of attending our exhibition?', or 'What motivates people to visit our museum?'. Next, think about who you will be consulting with and what data collection methods will best suit them, for example, focus groups or surveys.

When planning your evaluation, consider asking consultees both open and closed questions. Closed questions can be answered by a word or short phrase - for example, 'yes' or 'no' - or ask consultees to select an answer

15 ADAMS, Marianna. Museum Evaluation. Journal of Museum Education [online]. 2012, vol. 37, no. 2, p. 31 [cit. 2017-03-23]. Available from www: < http://dx.doi.org/10.1080/10598650.201 $2.11510728>$. 
from a set of predefined categories. Open questions invite thoughts and reflections and are useful for eliciting rich feedback from respondents. As an example: 'Did you enjoy your visit to the museum?' is a closed question, whilst 'Describe your experience at the museum' is an open question. Open questions can be more useful for inviting dialogue between the museum and audiences as respondents are more able to give considered, unstructured opinions.

When deciding which questions to ask, you also need to consider which type of data you need to collect. Qualitative data is not in numerical form, for example, responses given in a focus group. This data describes how people think or feel. Open questions generate qualitative data.

Quantitative research is measured and written down in numbers, for example, ratings scales. Closed questions generate quantitative data. As an example: 'Tell us what you thought about your visit to the museum' would elicit qualitative data, whilst 'On a scale of 1-5, where 1 is poor and 5 is excellent, how did you rate your visit to the museum?' would elicit quantitative data.

\section{Methods of data collection}

When planning the evaluation, you need to decide which methods of data collection you will utilise. This section of the paper describes several consultation methods you may wish to use to conduct evaluation. ${ }^{16}$

16 The paper does not provide an exhaustive list of every consultation method. Several excellent resources provide further information, including the Evaluation toolkit for museum practitioners, which has been an invaluable help to me since I was first introduced to it in 2010. FOSTER, Harriet. Evaluation toolkit for museum practitioners [online]. Norwich: Renaissance East of England, 2008 [cit. 2010-08-27]. Available from www: <http://sharemuseumseast.org.uk/shares/resource_34.pdf $>$.
It is helpful to collect data from a number of sources so that you can cross-reference your findings and validate the data. However, it is important that the evaluation is feasible; make sure your evaluation is focused and workable within the resources and capacity you have at your disposal. If capacity is an issue, you could consider whether it might be possible to build evaluation capacity through cross-institutional working. Steele-Inama, describes the work of the Denver-area Evaluation Network (DEN), a group set up by museum professionals in 2010 that works together to conduct cross-institutional evaluation studies, as well as sharing ideas and experiences with each other. ${ }^{17}$ In its first 18 months, the Network conducted a joint demographic survey, visitor motivation survey and institutional value assessment. ${ }^{18}$

\section{$\underline{\text { Surveys }}$}

Surveys can be used to collect data about a range of subjects, including respondents' demographic data, perceptions, and likes and dislikes. They can either be self-completed by consultees or completed by a facilitator who asks questions of consultees. It is helpful to include a mixture of closed and open questions; the former take less time to complete and analyse, which is helpful to both consultees and evaluators, and the latter gives consultees the opportunity to give more personal responses that allow for a richer narrative.

When writing survey questions, be careful not to ask questions that lead consultees into giving certain responses. 'When will you next

\footnotetext{
17 STEELE-INAMA, Marley. Building Evaluation Capacity as a Network of Museum Professionals. Journal of Museum Education [online]. 2015, vol. 40, no. 1, p. 79 [cit. 2017-03-16]. Available from www: <http://www.tandfonline.com. ezproxy4.lib.le.ac.uk/doi/pdf/10.1080/10598650. 2015.11510836 ? needAccess $=$ true $>$.

18 Ibidem, p. 79.
}

visit the museum?', for example, implies that the consultee will definitely visit the museum again, and perhaps assumes they enjoyed their visit, whereas, 'Do you intend to visit the museum again? Please give a reason for your answer' is a neutral question that makes no assumptions as to whether the consultee will visit in the future.

Consider how much time it will take consultees to complete the survey and, if you are able, make this clear to people before they begin the survey in order to manage expectations. If possible, it is advisable to design a survey that takes no longer than 5 minutes to complete so consultees are not asked to give a great deal of time to support the evaluation.

\section{$\underline{\text { Focus groups }}$}

A focus group is a facilitated group discussion in which the facilitator guides the group through a list of topics. During the session, the facilitator should try to let the conversation flow between participants, trying to elicit responses from all participants, and should ask questions that explore reasons for consultees' answers, for example, 'Why do you feel that way?'. If possible, it is helpful for a neutral observer to be at the session to record notes and observations and help keep the session to time.

Focus groups do not solely have to involve the facilitator asking questions of the group; some facilitators ask consultees to take part in interactive activities, such as working as a group to write or draw responses to a question then feeding their responses back to the facilitator, or asking the group to respond to a set of images. Activities can be particularly helpful when conducting focus groups with children and young 
people as they can help set an informal and relaxed atmosphere.

\section{$\underline{\text { Interviews }}$}

Interviews support evaluators to collect rich qualitative data about a range of subjects. Interviewers can either ask consultees a list of set questions - known as structured interviews - or ask the consultee about specific topics and asking questions that stem from the consultee's responses - known as semi-structured interviews. Interviews can be conducted faceto-face or via telephone or digital methods such as Skype.

\section{$\underline{\text { Vox pops }}$}

Vox pops enable evaluators to collect short responses from consultees by asking one or two simple questions. Vox pops are conducted face-to-face and can be recorded on a digital voice recorder or video camera.

\section{Observation}

This method involves observing what visitors do in a museum or gallery space. You could observe, for example, which exhibits attract the most and least visitors, how visitors engage with interactives, and how long visitors spend at each exhibit or in each gallery. As well as recording observations, you should also make a note of basic demographics about each visitor who you observe, such as age category and gender, to enable you to compare and contrast the behaviour of different demographic groups.

\section{Graffiti wall}

Graffiti walls enable evaluators to collect visitor responses to a specific question, such as 'Tell us what you thought about your visit to the museum'. Visitors are invited to write or draw their answers on cards or post-it notes and then stick these on a board or large sheet of paper. To help make this method of consultation more playful, you could give visitors response cards that are themed to match the themes of the museum - for example, a railway museum might use cards in the shape of trains.

\section{$\underline{\text { Voting jars }}$}

This method of evaluation involves asking visitors a question and getting them to place a button or counter in the jar that represents their answer. For example, you could ask, 'What was your favourite gallery in the museum?' and set up a series of jars that are each labelled with the name of one of the galleries.

\section{Measuring impact}

Munley suggests that, in order to demonstrate the public value of museums, institutions must be able to show that they are doing social good; ${ }^{19}$ that their work is having positive impacts on individuals and communities. Impact is about the effect that a museum visit, programme or project has on visitors, or the different it makes to someone - for example, they may have learnt a new skill that has helped them get a job or increased their self-confidence.

\section{Measuring and demonstrating} impact requires looking at more than numbers, ${ }^{20}$ such as number of visitors; numbers alone do not describe how the difference the museum has made to people's lives. ${ }^{21}$ The inclusive museum must

\footnotetext{
19 MUNLEY, Mary Ellen. Raising the Bar. Journal of Museum Education [online]. 2010, vol. 35, no. 1, pp. 22-23 [cit. 2017-03-23]. Available from www: $<$ http://dx.doi.org/10.1080/10598650.2010.115 10647>.

20 Ibidem, p. 22.

21 PRESKILL, Hallie. Museum Evaluation

without Borders: Four Imperatives For Making Museum Evaluation More Relevant, Credible, and
}

explore how the changes that have occurred as a result of the visit, programme or project; in other words, if and how the museum has made a difference to people's lives.

When measuring the impact of projects and programmes, remember that it is difficult perhaps impossible - to prove that a specific project or programme is the only factor that has made a difference to someone's life. For example, learning a new skill may have helped someone get a job, but other factors may also have contributed to this outcome, such as a job becoming available and the person writing a good application form and performing well at interview. When writing up evaluations, be careful not to overclaim success, or to solely attribute outcomes to a project or programme if the reality is more complex.

\section{$\underline{\text { Generic Learning Outcomes }}$}

The Generic Learning Outcomes (GLOs) are a tool by which museums can explore and analyse the impact of learning in museums, libraries and archives. ${ }^{22}$ The GLOs have five categories that encompass the breadth of learning that visitors may describe: ${ }^{23}$

\section{- Knowledge and} Understanding - learning new information or gaining a deeper understanding of a topic.
Useful. Curator. The Museum Journal [online]. 2011, vol. 54, no. 1, pp. 94-95 [cit. 2017-22-03]. Available from www: < http://onlinelibrary.wiley. com.ezproxy4.1ib.le.ac.uk/doi/10.1111/j.21516952.2010.00072.x/epdf $>$.

22 RESEARCH CENTRE FOR MUSEUMS AND GALLERIES. Measuring the Outcomes and Impact of Learning in Museums, archives and Libraries. Learning Impact Research Project. End of Project Paper, 07 May 2003 [online]. 2003, p. 11 [cit. 2017-0316]. Available from www: <https://www2.le.ac. uk/departments/museumstudies/rcmg/projects/ lirp-1-2/LIRP $\% 20$ end $\% 20$ of $\% 20$ project $\% 20$ paper. pdf $>$.

23 Ibidem, p. 11. 
- Skills - learning how to do something or developing a skill.

- Attitudes and Values - changing feelings or perceptions about oneself, people, things or the world, increased empathy or tolerance, increased motivation.

\section{- Enjoyment Inspiration}

Creativity - having fun or

being surprised, being inspired, exploring, experimenting, making.

\section{- Activity Behaviour and}

Progression - what people do, intend to do or have done as a result of visiting a museum. ${ }^{24}$

To explore the learning impacts of museums upon visitors, evaluators can ask visitors questions that relate to the GLOs, such as 'Tell us what, if anything, you learnt in the museum today'. The Arts Council England website features a set of tools and templates that support practitioners to record and analyse the GLOs. ${ }^{25}$

\section{UCL Museum Wellbeing Measures $\underline{\text { Toolkit }}$}

Researchers from University College London (UCL) Museums and Public Engagement have produced a toolkit that supports practitioners to assess the impact of their work on people's mood and emotions. ${ }^{26}$ The toolkit includes simple exercises that assess, for example, the impact of activities upon happiness levels, how

\footnotetext{
24 Ibidem, pp. 12-17.

25 ARTS COUNCIL ENGLAND. Generic Learning Outcomes - tools and templates. In Arts Council England website [online]. England: Arts Council England [cit. 2017-03-23]. Available from www: $<$ http://www.artscouncil.org.uk/measuring-outcomes/generic-learning-outcomes\#section-8>.

26 THOMSON, Linda J. and Helen J. CHATTERJEE. UCL Museum Wellbeing Measures Toolkit [online]. London: UCL Museums \& Public Engagement, 2013, p. 3 [cit. 2017-02-10]. Available from www: <https://www.ucl.ac.uk/culture/sites/culture/files/ucl_museum_wellbeing_measures_toolkit_sept2013.pdf $>$.
}

engaged, comfortable and safe people feel, how much they enjoyed others' company, how much they talked to people, how interested they were in the activity, and how confident and healthy they feel as a result of participating in the activity. Exercises in the toolkit can be used to assess the impact of both one-off activities or longer programmes.

\section{Longitudinal data comparisons}

One way to assess the impacts of activities, projects or programmes is to obtain baseline data from people before they participate in an activity and again at the end of, and/or after, participation. You might, for example, record a student's literacy levels prior to them taking part in a project that aims to increase literacy and then at the end of the project to enable you to assess the extent to which the student's literacy levels may have improved.

Limited resources mean that it can be difficult to continue to record data for months and years after a project or programme has come to an end. It may be worth considering allocating extra budget to the evaluation to enable you to conduct this type of very longterm evaluation, particularly if the impacts of your project or programme not be immediate or may continue to be felt over a long period of time - for example, a project that raises educational attainment might lead to a student's grades improving over several years.

\section{Recruiting consultees}

When planning your evaluation, consider how you are going to recruit consultees. Firstly, think about who you are trying to reach is this, for instance, local families, teachers, young people, older people, visitors, non-visitors? Once you have decided upon your target audiences, consider how you will reach consultees. For example, if you wish to speak to people who already visit your museum, you might talk to them during a visit or recruit them to a focus group by promoting the group on social media or a newsletter. Non-visitors are harder to recruit. Think about where they hang out - such as local community centres, shopping centres or libraries - what they read and what social media sites they might be on, and advertise through these channels.

Make sure you build in enough time to recruit consultees; this can be incredibly time-consuming, particularly if you are consulting with non-visitors who are not known to your museum and who may never have heard of your museum.

\section{Data analysis}

Before conducting deep analysis of the data, Foster suggests it is useful to read through all the data you have collected to start to understand some of the themes that are emerging. ${ }^{27}$ Think about the most popular answers to questions and whether consultees tend to broadly agree with one another or not, and why this might be. Following this initial analysis, commence an in-depth interrogation of the data, looking for numbers of responses and popularity of responses, themes, any outlying responses and reasons for this, and responses in relation to demographics - for instance, consider whether people of certain genders or ages tend to give similar answers.

27 FOSTER, Harriet Evaluation toolkit for museum practitioners [online]. Norwich: Renaissance East of England, 2008, p. 54 [cit. 2010-08-27]. Available from www: <http://sharemuseumseast. org.uk/shares/resource_34.pdf $>$. 
When analysing data, try to ensure you eliminate bias as much as possible. Enter the analysis process with an open mind; having strong assumptions about what you will find may mean that you specifically look for data that backs up these assumptions. Involving more than one person in the analysis can support the elimination of bias. People who have previously not been involved in the evaluation process may also bring fresh insights and reveal new information. Analysis could be supported by internal colleagues or an external consultant.

\section{Disseminating and acting upon evaluation}

Evaluation findings can be disseminated in a number of ways, including written reports, oral presentations, infographics, noticeboards and newsletters. When planning your dissemination, consider who you are reporting to for instance, funders, audiences, staff - and which dissemination methods are most appropriate for the audience. Funders may have specific requirements regarding how evaluation is disseminated, or may prefer more formal, written reports. Oral presentations can be a useful way of disseminating to staff members as this method offers the opportunity for people to ask questions and respond to findings. Audiences may prefer to view findings - and, if possible, what you intend to do as a result of these findings - on a noticeboard located in a public space in the museum.

If appropriate, consider sharing your findings with other institutions; as Adams states, evaluations are rarely shared yet this act supports museums to learn from each other. ${ }^{28}$

28 ADAMS, Marianna. Museum Evaluation. Journal of Museum Education [online]. 2012, vol. 37, no. 2, pp. 32-33 [cit. 2017-03-23]. Available from
It is crucial to act on the findings of your evaluation. Ignoring the research does a disservice to the people with whom you have consulted and, in the long-term, may lead to decreasing visitor numbers, unengaged visitors and unmotivated staff. In addition, a lack of action means that the time and money invested in conducting the evaluation has been wasted. Consider how your findings will influence or change your practice and take steps to make this happen. Depending on your budget and capacity, it may not be feasible to implement all the changes immediately; consider which are the most important things to do or change and put these into action as soon as possible.

\section{Concluding thoughts}

Evaluation and consultation are essential components of the inclusive museum, enabling museum staff to gain and develop a deep understanding of audiences. To conduct effective evaluation, it is important to spend time planning the process, ensuring it is feasible, appropriate, measures impacts as well as numbers, and that it suits audience needs. A range of methods can be used to collect data and evaluators should aim to utilise more than one method in order to cross-reference findings and validate the data. Work with others during the data analysis phase to gain fresh insights and reduce bias. Following analysis, disseminate the evaluation and, if possible, share your findings with other museums in order to support sector learning and development. Dissemination is not enough; acting on the findings of evaluation demonstrates a commitment to audience-centered practice and supports museums to maintain their relevance. The inclusive

www: <http://dx.doi.org/10.1080/ 10598650.2012.11510728>. museum does not undertake evaluation for evaluation's sake; rather, it listens to and collaborates with its audiences, putting audience needs at the heart of its practice.

\section{BIBLIOGRAPHY:}

ADAMS, Marianna. Museum Evaluation. Journal of Museum Education [online]. 2012, vol. 37, no. 2, pp. 25-35 [cit. 201703-23]. ISSN 1059-8650. DOI: http://dx.doi org/10.1080/10598650.2012.11510728

ARTS COUNCIL ENGLAND. Generic Learn-

ing Outcomes - tools and templates. In Arts Council England website [online]. England: Arts Council England [cit. 201703-23]. Available from www: < http:// www.artscouncil.org.uk/measuring-outcomes/generic-learning-outcomes\#section-8>.

BLACK, Graham. The Engaging Museum. Developing Museums for Visitor Involvement [online]. London and New York: Taylor and Francis, 2005 [cit. 201703-23]. Available from www: <http:// ebookcentral.proquest.com.ezproxy3.lib. le.ac.uk/lib/leicester/detail.action?do$\mathrm{cID}=1075158>$. ISBN 0-415-34557.

FLEMING, David. Dr David Fleming: "What does the democratic museum look like?". In National Museums Liverpool Blog [online]. Liverpool: National Museums Liverpool, 2014 [cit. 2017-03-23]. Available from www: <http://blog.liverpoolmuseums.org.uk/2014/07/dr-david-flemingwhat-does-the-democratic-museum-looklike/ $>$.

FOSTER, Harriet. Evaluation toolkit for museum practitioners [online]. Norwich: Renaissance East of England, 2008 [cit. 2010-08-27]. Available from www: <http://sharemuseumseast.org.uk/ shares/resource_34.pdf $>$.

LUKE, Jessica J. and Jeanine E. ANCELET. The Role of Evaluation in Reimagining the Art Museum. Journal of Museum Education [online]. 2014, vol. 39, no. 2, pp. 197-206 [cit. 2017-03-16]. Available from www: <http://www.tandfonline. com.ezproxy4.lib.le.ac.uk/doi/pdf/10.1 080/10598650.2014.11510810?needAccess $=$ true $>$. ISSN 1059-8650. 
MUNLEY, Mary Ellen. Raising the Bar. Journal of Museum Education [online]. 2010, vol. 35, no. 1, pp. 21-32 [cit. 2017-03-23]. ISSN 1059-8650. DOI: http://dx. doi.org/10.1080/10598650.2010.11510647

PRESKILL, Hallie. Museum Evaluation without Borders: Four Imperatives For Making Museum Evaluation More Relevant, Credible, and Useful. Curator. The Museum Journal [online]. 2011, vol. 54, no. 1, pp. 93-100 [cit. 2017-22-03]. Available from www: <http://onlinelibrary.wiley. com.ezproxy4.lib.le.ac.uk/doi/10.1111/ j.2151-6952.2010.00072.x/epdf > . ISSN 2151-6952.

RESEARCH CENTRE FOR MUSEUMS AND GALLERIES. Measuring the Outcomes and Impact of Learning in Museums, archives and Libraries. Learning Impact Research Project. End of Project Paper, 07 May 2003 [online]. 2003 [cit. 2017-03-16]. Available from www: <https://www2.le.ac. uk/departments/museumstudies/rcmg/ projects/lirp-1-2/LIRP\%20end\%20of $\% 20$ project $\% 20$ paper.pdf $>$.

STEELE-INAMA, Marley. Building Evaluation Capacity as a Network of Museum Professionals. Journal of Museum Education [online]. 2015, vol. 40, no. 1 , pp. 78-85 [cit. 2017-03-16]. Available from www: <http://www.tandfonline. com.ezproxy4.lib.le.ac.uk/doi/pdf/10.1 080/10598650.2015.11510836?needAccess $=$ true $>$. ISSN 1059-8650.

STUFFLEBEAM, Daniel and Chris L. S. CORYN. Evaluation Theory, Models, and Applications [online]. $2^{\text {nd }}$ ed. New York: John Wiley \& Sons Inc, 2014 [cit. 2017-03-23]. Available from www: <http:// ebookcentral.proquest.com.ezproxy3.lib. le.ac.uk/lib/leicester/detail.action?do$\mathrm{cID}=1801247>$. ISBN 978-1-11807405-3.

THOMSON, Linda J. and Helen J. CHATTERJEE. UCL Museum Wellbeing Measures Toolkit [online]. London: UCL Museums \& Public Engagement, 2013 [cit. 201702-10]. Available from www: <https:// www.ucl.ac.uk/culture/sites/culture/ files/ucl_museum_wellbeing_measures_ toolkit_sept2013.pdf >.

\section{LAURA CROSSLEY}

School of Museum Studies, University of Leicester, UK 